\title{
ArcheoSciences
}

Revue d'archéométrie

$36 \mid 2012$

Varia

\section{Direct 14C-dating of Roman and late antique purple dye sites by murex shells}

Datation directe par le radiocarbone de coquillages murex provenant de

teintureries de l'Antiquité romaine et tardive

Mark Van Strydonck, Mathieu Boudin and Damià Ramis

\section{CpenEdition}

Journals

Electronic version

URL: https://journals.openedition.org/archeosciences/3687

DOI: 10.4000/archeosciences.3687

ISBN: 978-2-7535-2243-5

ISSN: $2104-3728$

Publisher

Presses universitaires de Rennes

Printed version

Date of publication: 31 December 2012

Number of pages: $15-23$

ISBN: 978-2-7535-2241-1

ISSN: $1960-1360$

\section{Electronic reference}

Mark Van Strydonck, Mathieu Boudin and Damià Ramis, "Direct 14C-dating of Roman and late antique purple dye sites by murex shells", ArcheoSciences [Online], 36 | 2012, Online since 31 December 2014, connection on 28 January 2022. URL: http://journals.openedition.org/archeosciences/3687 ; DOl: https://doi.org/10.4000/archeosciences.3687 


\title{
Direct ${ }^{14} \mathrm{C}$-dating of Roman and Late Antique Purple Dye Sites by Murex Shells
}

\author{
Datation directe par le radiocarbone de coquillages murex provenant \\ de teintureries de l'Antiquité romaine et tardive
}

\author{
Mark VAN STRYdoncK*, Mathieu Boudin* and Damià Ramis**
}

\begin{abstract}
Until late antique times, murex shells were used for the production of true purple. Murex production sites are found all around the Mediterranean. In this paper are studied four sites from the Balearic Islands. Radiocarbon dates from animal bones and charcoal supposed to be synchronic with the murex dye production, are compared to direct dating of the murex shells. In all but one case the terrestrial samples were inconsistent. The murex shells on the other hand yielded coherent results. The charcoal and the animal bones were without any doubt intrusive. Consequently the ideal radiocarbon sampling strategy should exhibit a good equilibrium between sample quality and sample integrity.
\end{abstract}

Résumé : Jusqu'à la fin de l'Antiquité, les coquilles de murex étaient utilisées pour la production de la véritable pourpre. Des sites de production de murex ont été découverts sur tout le pourtour méditerranéen. Le présent article étudie quatre sites des Iles Baléares. Les datations radiocarbones d'os d'animaux et de charbon de bois, censés être concomitants de la production de teinture à partir du murex, sont comparées avec les datations directes des coquilles de murex. Sauf dans un cas, les échantillons terrestres étaient contradictoires. D’un autre côté, les coquilles de murex fournissaient des résultats cohérents. Le charbon de bois et les os d'animaux étaient donc sans nul doute parasites.

En conséquence, la stratégie d'échantillonnage radiocarbone idéale reposerait sur un bon équilibre entre la qualité de l'échantillon et son intégrité.

Keywords: radiocarbon dating, murex, sample integrity, Balearic islands.

Mots clé : datation par le radiocarbone, murex, intégrité des échantillons, Îles Baléares.

\section{INTRODUCTION}

First used by the Phoenicians, murex shells were used for the production of true purple until late antique times (Gleba and Vanden Berghe, in print). Murex production sites are found all around the Mediterranean, and the Balearic Islands form no exception (Costa, 2009). The purple dyestuff is not present in the living animal, but after the animal dies it can develop through enzymatic hydrolysis of uncoloured components. This process has to be initiated immediately after collection of the shells. During this preparation an unpleasant smell is produced (rotting of the animal), hence it was forbidden to perform this activity in urban areas. Consequently purple dye production was done on site. As a result these sites contain very limited archaeological remains, except for large quantities of murex shell debris (Alfaro $e t$ al., 2004). In this paper shells, charcoal and bones coming from 4 Balearic sites were analysed by radiocarbon dating in order to date their use. All shells analysed in this study are Murex trunculus( figure 1).

\footnotetext{
* Royal Institute for Cultural Heritage, Jubelpark 1, 1000 Brussels, Belgium Mark.vanstrydonck@kikirpa.be

** Natural History Society of the Balearic Islands, Margarida Xirgú 16, 07011 Palma de Mallorca, Balearic Islands, Spain
} 


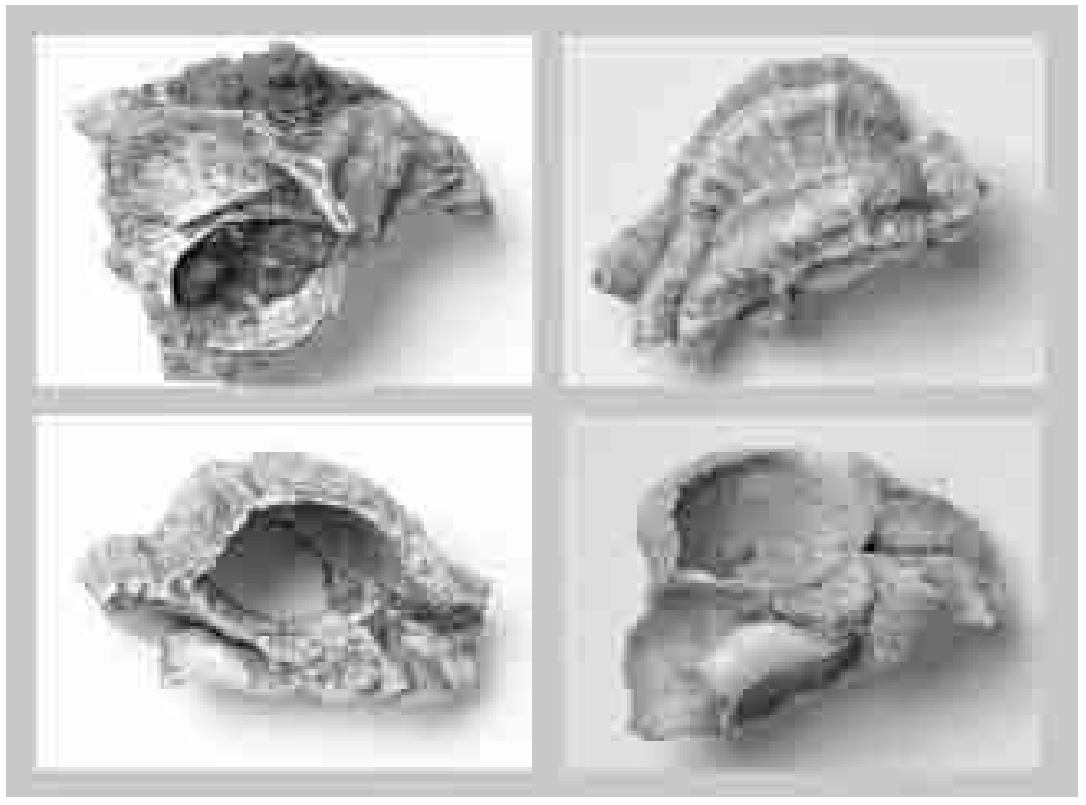

Figure 1: (See colour plate) Murex trunculus from purple dye production sites.

Figure 1: (Voir planche couleur) Murex trunculus provenant d'une site de production de la teinture pourpre.



Figure 2: (See colour plate) The Balearic Islands: 1) Cabrera; 2) Pedret de Bóquer; 3) Pou des Lleó - Cala Olivera. Figure 2: (Voir planche couleur) Les Îles Baléares : 1) Cabrera ; 2) Pedret de Bóquer ; 3) Pou des Lleó- Cala Olivera. 


\section{Materials AND METHODS}

\section{Sample selection}

\section{Mallorca}

\section{Cabrera}

A letter written by Pope Gregorius Magnum in 603 AD gives unmistakable evidence of the presence of a monastic congregation in the Cabrera Archipelago. Several locations near the port of Cabrera showed evidence of the presence of monks on the archipelago including a necropolis overlaying a purple dye tannery with a high concentration of murex debris (Riera, 2010; Riera \& Riera, 2005; Ramis \& Pons, 2005). Bone samples from domesticated animals (goat) and murex shells from two locations were analyzed, both supposed to date from the period of the Roman purple dye production (figure 1).

\section{Pedretd eBóqu er}

Located just outside the port of Pollença, this is the area where the Civitas Bocchoritana was supposedly founded. During the excavation a reservoir lined with mortar was found together with a lot of shells, most of them murex (Estarellas \& Merino, 2005). Samples from domesticated animals (bovine and goat) and murex samples, both supposed to date from the period of the purple dye production, were analysed.

\section{Ibiza}

\section{Poud esLleó}

The site of Canal d'en Martí is located in the Cala del Pou des Lleó, at the north-east coast of Ibiza. It has been recognized as a well-organized area for purple dye production, with a long history. Some architectural remains were recorded: mainly some pits and very eroded walls. The seashell debris related to purple production is very abundant and the characteristic breakage patterns of the specimens are quite common (Alfaro et al., 2002, 2004). In this case charcoal and murex shells were dated, both supposed to date from the period of the purple dye production.

\section{CalaO livera}

Cala Olivera is situated near the city of Ibiza, on the east coast of the island. A small collection of seashells - mainly murex - has been excavated there. The archaeological site is interpreted as a small purple dye workshop without any visible architectonic remains (Costa \& Alfaro, 2007; Alfaro \& Costa, 2008). Also in this case charcoal and murex shells were dated, both supposed to date from the period of the purple dye production.

\section{Sample pre-treatment}

Collagen from the bone samples was extracted following the Longin method (Longin, 1971) with an additional $\mathrm{NaOH}$-wash. Collagen quality was tested by C:N (carbon/ nitrogen) ratio and collagen yield. A small portion of each collagen sample was transferred in duplicate into tin capsules, which were analyzed using a ThermoFinnigan delta $+\mathrm{XL}$ (continuous flow type) isotopic mass spectrometer, interfaced with a Flash EA1112 elemental analyzer via a Conflo III interface. Both elements were measured together and a Helium-dilution was applied for carbon as the amount of $\mathrm{C}$ is much greater than the amount of $\mathrm{N}$ in the samples. Furthermore the visual appearance of the collagen and the amount of retrieved collagen were considered (Van Strydonck et al., 2005).

Charcoal was successively washed in hot $\mathrm{HCl}(1 \%)$, $\mathrm{NaOH}(1 \%)$ and $\mathrm{HCl}(1 \%)$ (acid-alkali-acid) method and then again washed with Milli-Q water and dried (Van Strydonck et al., 2010).

Shells were cleaned by removing the surface layer of the shell. Sample quality was checked by $\delta^{13} \mathrm{C}$ measurements (marine samples have $\delta{ }^{13} \mathrm{C}>0 \%$ ) using a FinniganMat- $\delta$ isotopic mass spectrometer and the crystal structure was measured by XRD using a Bruker-D8. The XRD measurements are necessary because in the case of marine carbonates, contamination appears usually in the form of secondary low-magnesium calcite - the stable polymorph of calcium carbonate $\left(\mathrm{CaCO}_{3}\right)$ - and byproduct of the postmortem recrystallization or replacement of the autochthonous phase, originally in the form of high-magnesium calcite or aragonite. Depending on the nature of the depositional environment, the recrystallized phase may be contemporary in age with the original shell- $\mathrm{CaCO}_{3}$ and may have even derived from it by dissolution-recrystallization reactions, or can be an exogenous contaminant of younger or older age (Magnani et al., 2007).

\section{Graphitization and AMS measurements}

$\mathrm{CO}_{2}$ from the organic samples (charcoal and collagen) was obtained by combustion (in the presence of $\mathrm{CuO}$ ) and in the case of shells by extraction with phosphoric acid $\left(\mathrm{H}_{3} \mathrm{PO}_{4}\right)$.

Graphitisation of $\mathrm{CO}_{2}$ was carried out using $\mathrm{H}_{2}$ over a Fe catalyst.

Targets were prepared at the Royal Institute for Cultural Heritage in Brussels (Belgium) (M. Van Strydonck, K. van der Borg 1990-91) and measured at the Leibniz Labor für Altersbestimmung und Isotopenforschung in Kiel (Germany) (Nadeau et al., 1998). 


\section{RESULTS AND DISCUSSION}

\section{Results}

All results are summarized in table 1 , the uncalibrated radiocarbon results are depicted in figure 3 .

\section{Discussion}

\section{Samplequ alityc ontrol}

All charcoal samples resisted very well the AAA pre-treatment.

The quality of the bones was also very good. Although the amount of collagen was sometimes low, other parameters such as the C:N ratio, and the general appearance of the collagen were excellent. $\delta^{13} \mathrm{C}$ and $\delta^{15} \mathrm{~N}$ correspond to terrestrial herbivores, no shift due to contamination was observed (Van Strydonck et al. 2005).

All shells show positive $\delta^{13} \mathrm{C}$ values, indicating a $100 \%$ marine provenance of the carbon. In some of the samples however calcite was detected. The presence of calcite is a strong indication of the presence of secondary carbonate. This secondary carbonate can have a different ${ }^{14} \mathrm{C}$ signal than the original aragonite from the murex shells. Fortunately our results exclude this possibility. All murex shells from UE501 at Bóquer statistically have the same age although one of the samples contains about $16.2 \%$ calcite. The murex samples from Cabrera statistically have the same age as well, in spite of the presence of different amounts of calcite. This proves that the deposition of secondary carbonate happened shortly after the shells were harvested. This situation is in agreement with the production process of the purple dye.

\section{Samplein tegrity}

While the sample quality concerns the reliability of the ${ }^{14} \mathrm{C}$ date, the relation between the samples age and the archaeological phenomenon to be dated is defined by the sample integrity. There should be a close relationship between the radiocarbon age of the material and the human event of interest (Van Strydonck et al., 1999). Only in the case of the Bóquer samples the differences in age between the marine murex shells and the terrestrial bones from domesticated animals are almost constant as one should expect from marine/terrestrial pairs with the same real age (figure 3, table 1). Using the Bóquer samples to calculate the $\Delta \mathrm{R}$ value (local deviation from the global ocean reservoir age)for the Mediterranean surface waters around the Balearic archipelago, a value of $26 \pm 24{ }^{14} \mathrm{C}$ year is obtained (Van Strydonck et al., 2010). It should be noted here that the used $\Delta \mathrm{R}$ value is in agreement with previous research (Siani et al.,2000)

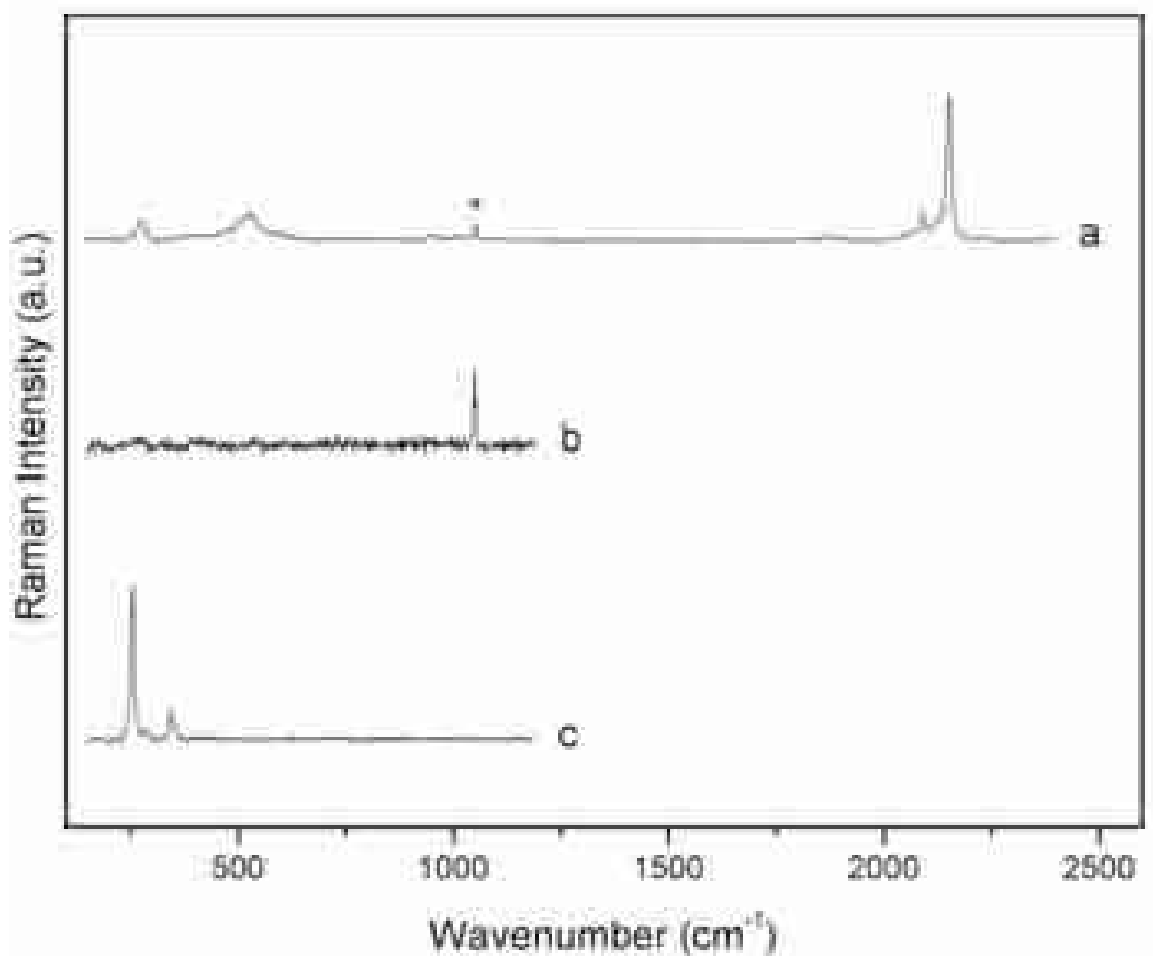

Figure 3: uncalibrated radiocarbon analyses (BP).

Figure 3 : analyses radiocarbone non calibrées $(B P)$. 


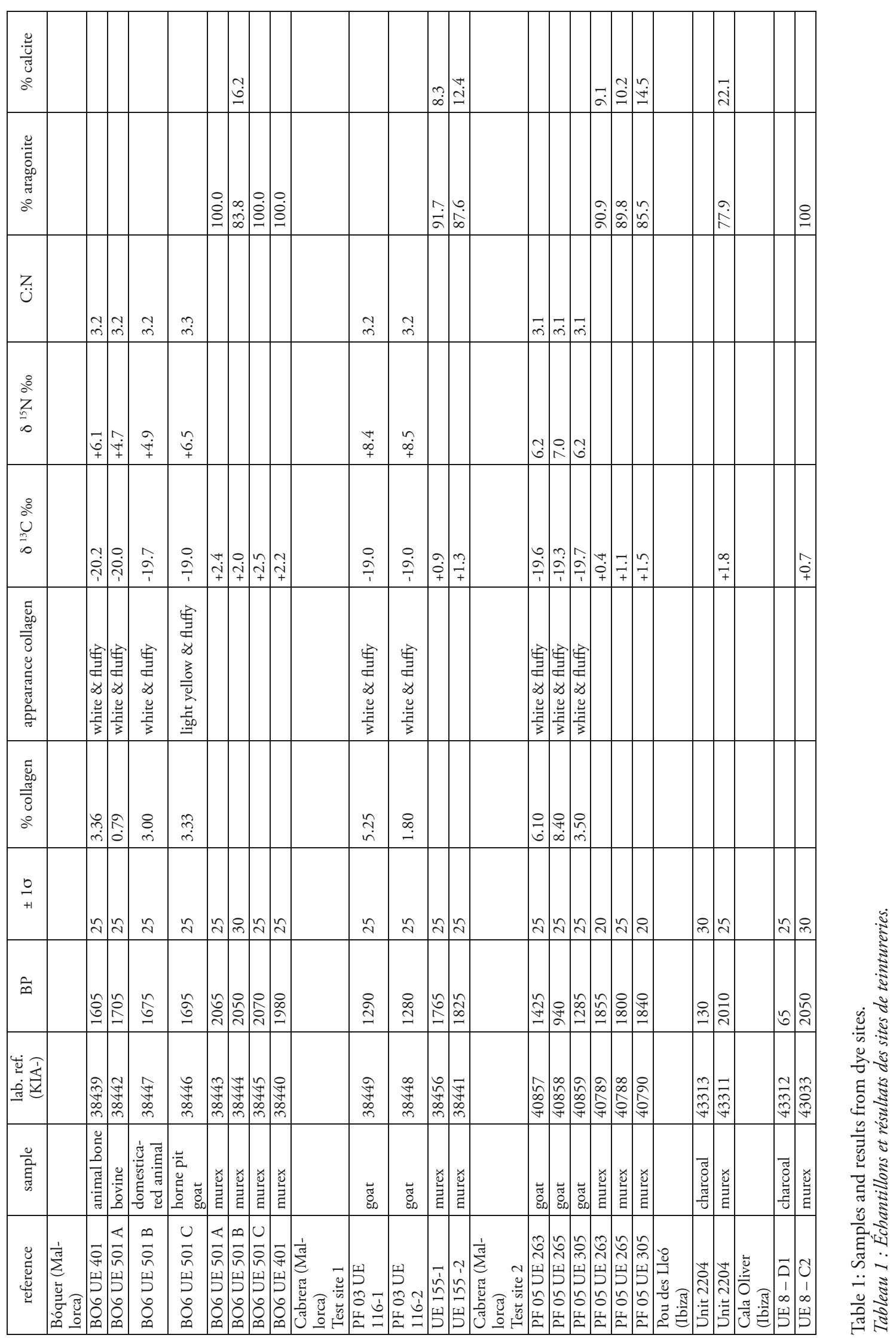


In the case of the Cabrera samples important age differences are observed between the terrestrial samples $\left[\chi^{2}\right.$ test fails: $\mathrm{df}=4, \mathrm{~T}=204.014(5 \%=9.5)]$. The murex samples on the other hand form a much more coherent series.

In the case of the two sites from Ibiza, the charcoal samples are unrealistically young.

Figure 3 depicts the calibrated radiocarbon results (Bronk Ramsey 2001) using the marine data from Reimer et al. (2009) and a $\Delta \mathrm{R}=26 \pm 24{ }^{14} \mathrm{C}$ year for the different sites and units, calculated from the murex dates. From Bóquer UE 501 as well as from Cabrera PF05 the average of 3 results is calculated, from Cabrera 155 the average of 2 results is calculated. A $\chi^{2}$ test shows that samples originating from the same layer can have the same real age. The results are also summarized in table 2 .
The results in table 2 and figure 4 are coherent and correspond to the archaeological expectations. This is not the case for the charcoal samples and the bones from domesticated animals, both yielding dates that are contradictory and too recent.

\section{ConClusion}

Most archaeologists prefer terrestrial samples to marine samples for dating because the marine reservoir age of large parts of the world is unknown and because of the possibility of contamination. In many cases however sample integrity should be a much more decisive factor than sample quality. There is a much more direct relationship between

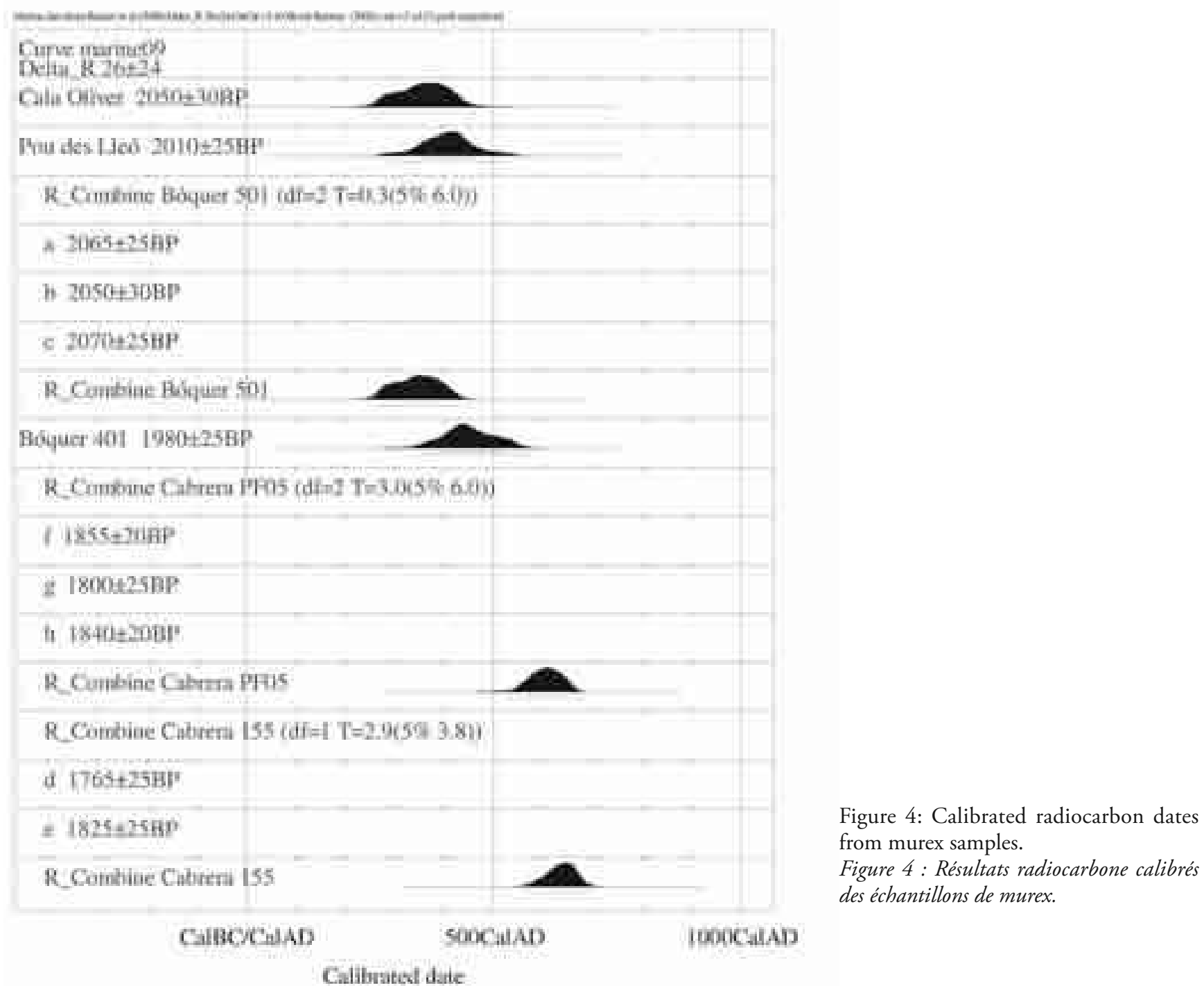

ArCheoSCIEnCes, revue d'archéométrie, 36, 2012, p. 15-22 
Table 2: Calibrated radiocarbon dates from murex shells. Tableau 2 : Dates radiocarbones calibrés des coquillages de murex

\begin{tabular}{|c|c|}
\hline $\begin{array}{l}\text { CalaO liver: } 2050 \pm 30 \mathrm{BP} \\
300 \mathrm{AD}(68.2 \%) 430 \mathrm{AD} \\
240 \mathrm{AD}(95.4 \%) 460 \mathrm{AD}\end{array}$ & 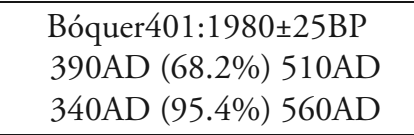 \\
\hline $\begin{array}{l}\text { Poud esLleó:2010 } \pm 25 \mathrm{BP} \\
350 \mathrm{AD}(68.2 \%) 460 \mathrm{AD} \\
290 \mathrm{AD}(95.4 \%) 530 \mathrm{~A} \mathrm{D}\end{array}$ & $\begin{array}{c}\text { CabreraPF05:1836 } \pm 12 \mathrm{BP} \\
\text { 570AD }(68.2 \%) 645 \mathrm{AD} \\
\text { 530AD }(95.4 \%) 680 \mathrm{AD} \\
\chi 2 \text {-Test:d f=2 T=3.0(5\%6. } 0)\end{array}$ \\
\hline 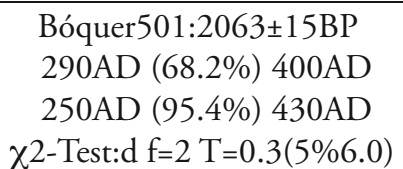 & $\begin{array}{c}\text { Cabrera } 155: 1795 \pm 18 \mathrm{BP} \\
\text { 610AD }(68.2 \%) 670 \mathrm{AD} \\
\text { 560AD }(95.4 \%) 700 \mathrm{AD} \\
\chi 2 \text {-Test:d f=1 T=2.9(5\%3. 8) }\end{array}$ \\
\hline
\end{tabular}

the murex shells and the human event of interest - purple dye production - (Van Strydonck et al., 1999) than there is between this event and the bones or the charcoal found on site. Consequently the ideal radiocarbon sampling strategy should exhibit a good equilibrium between sample quality and sample integrity.

\section{Acknowledgements}

This study was financed by the European project DressID: Clothing and identities. New perspectives on textiles in the Roman empire.

\section{References}

Alfaro, C., Costa, B., TÉBAR, E., 2002 - Informe de la campaña de excavaciones de 2001en el Pou des Lleól Canal d'en Martí (Ibiza). Datatéxtil, 7, Terrassa : 45-53.

Alfaro, C., Costgener-bibliographya, B., Tébar, E., 2004 - Excavaciones al canal d'en Martí, en es Pou des Lleó 'Santa Eulària des Riu, durant els anys 2001-2003. Fites 4, Eivissa : $29-42$.

Alfaro, C., Costa, B., 2008 - Methodological aspects of purple dye production on Ibiza: the new site of Cala Olivera. In C. Alfaro \& L. Karali (eds.), PURPUREAE VESTES, II. Vestidos, Textiles y Tintes. Estudios sobre la producción de bienes de consumo en la antigüedad. Actas del II Symposium Internacional sobre Textiles y Tintes del Mediterráneo en el Mundo Antiguo (Atenas, 24 al 26 de noviembre, 2005). Valencia.

Bronk RAMSEY, C., 2001 - Development of the radiocarbon calibration program OxCal. Radiocarbon, 43(2A) : 355-363.

Costa, B., Alfaro, C., 2007 - Noves evidències de producció de porpra a Eivissa: actuacions arqueològiques dels anys 20052006. Fites, 7.

Costa Ribas, B., 2009 - La investigación de tejidos y tintos de la Antigüedad desde une perspectiva arqueológica: problemas y opor- tunidades. In Alfaro, C., Tellenbach, M., Ferrero, R. (eds.): Textiles y museología. Aspectos sobre el Estudio, Análysis y exposición de los Textiles Antiguos y de los instrumenta textilia. Actas del I Meeting Genereal. València: Universitat de València - Spain: 121-141.

Estarellas, M.M., Merino, J., 2005 - Treballs arqueologics preliminars al Pedret de Bóquer. In Barceló, M.L. \& Sánchez, M. (coord.), L'Antiguitat clàssica i la seva pervivència a les illes Balears. XXIII Jornades d'Estudis Històrics Locals. Palma : Institut d'Estudies Baleàrics : 377-393.

Gleba, M., Vanden Berghe, I., 2010 - Textiles from Strozzacapponi (Perugia/Corciano), Italy - new evidence of purple production in pre-Roman Italy. Actas del I Symposium Internacional sobre Textiles y Tintes del Mediteraneo en época romana, Valencia. Purpureae Vestes IV, in print.

Longin, R., 1971 - New method of collagen extraction for radiocarbon dating. Nature 230:241- 242.

Magnani, G., Bartolomei, P., Cavulli, F., Esposito, M., Marino, E. C., Neri, M., Rizzo, A., Scaruffi, S., Tosi, M., 2007 - U-series and radiocarbon dates on mollusc shells from the uppermost layer oft he archaeological site of KHB-1, Ra's al Khabbah, Oman. Journal of Archaeological Science, 34(5): 749-755.

Nadeau, M.-J., Grootes, P.M., Schliecher, M., Hasselberg, P., Rieck, A., Bitterling, M., 1998 - Sample throughput and data quality at the Leibniz-Labor AMS facility. Radiocarbon 40: 239-245.

Ramis, D., Pons, G.X., 2005 - Producció de colorant de púrpura a liilla de Cabrera. Bolletí de la Societat Arqueològica Lul.liana 61: 387-390.

Reimer, P., Baillie, M., Bard, E., Bayliss, A., Beck, J. W., Blackwell, P. G., Bronk Ramsey, C., Buck, C. E., Burr, G. S., Edwards, R. L., Friedrich, M., Grootes, P. M., Guilderson, T. P., Hajdas, I., Heaton, T. J., Hogg, A. G., Hughen, K. A., Kaiser, K. F., Kromer, B., McCormac, F. G., Manning, S. W., Reimer, R. W., Richards, D. A., Southon, J. R., Talamo, S., Turney, C. S. M., van der 
Plicht, J., Weyhenmeyer, C. E., 2009 - IntCal09 and Marine09 radiocarbon age calibration curves, 0-50,000 years cal BP. Radiocarbon 51(4): 1111-1150.

Riera, M.M. 2010 - Pla de ses Figueres (Isla de Cabrera, Baleares). In Morín, J., López Quiroga, J., Martínez Tejera, A. (eds.): El tiempo de los «bárbaros ». Pervivencia y transformación en Galia e Hispania (ss. V-VI d.C.). Madrid: Museo Arqueológico Regional, Zona Arqueológica 11: 581-594.

Riera, M.M., Riera, M., 2005 - Un possible taller de producció de porpra de l'antiguitat tardana al pla de ses Figueres (illa de Cabrera). Bolletí de la Societat Arqueològica Lul.liana 61 : 377-390.

Siani, G., Paterne, M., Arnold, M., Bard, E., Metivier, B., Tisnerat, N., Bassinot, F., 2000 - Radiocarbon reservoir ages in the Mediterranean Sea and Black Sea. Radiocarbon 42(2): 271-280.

VAN STRYdonck, M., vAN DER BorG, K., 1990-91 - The construction of a preparation line for AMS-targets at the Royal Institute for Cultural Heritage Brussels. Bulletin KIK/IRPA 23: 228-234.
Van Strydonck, M., Nelson, D.E., Crombé, P., Bronk Ramsey, C., Scott, E.M., van der Plicht, J., Hedges, R.E.M., 1999 - What's in a 14 C date. eds. J. Evin, C. Oberlin, J.-P. Daugas, J.-F. Salles, 3rd Int. Symposium ${ }^{14} \mathrm{C}$ and Archaeology, Mémoires de la Société Préhistorique Française 26, Supplément de la Revue d'Archéométrie, pp. 433-448.

Van Strydonck, M., Boudin, M., Ervynck, A., 2005 - Humans and Myotragus: the issue of sample integrity in radiocarbon dating. In Alcover, J.A. \& Bover, P. (eds.), Proceedings of the International Symposium "Insular Vertebrate Evolution: the Palaeontological Approach”. Monografies de la Societat d'Història Natural de les Balears, 12, pp. 369-376.

Van Strydonck, M., Boudin, M., Ramis, D., 2010 - Primer intent de mesurar l'edat del compartiment Marí de ${ }^{14} \mathrm{C}$ de les Aigües Costaneres de les Illes Balears. Endins 34: 181-188.

Van Strydonck, M., Boudin, M., Guerrero Ayuso, V. M., Calvo, M., Fullola, J. M., Petit, M.A., 2010 - The necessity of sample quality assessment in C AMS dating: The case of Cova des Pas (Menorca-Spain). Nuclear Instruments and Methods in Physics Research B 268 : 990-994. 